\title{
Corrigendum: A simple and versatile design concept for fluorophore derivatives with intramolecular photostabilization
}

Jasper H.M. van der Velde, Jens Oelerich, Jingyi Huang, Jochem H. Smit, Atieh Aminian Jazi, Silvia Galiani, Kirill Kolmakov, Giorgos Gouridis, Christian Eggeling, Andreas Herrmann, Gerard Roelfes

$\&$ Thorben Cordes

Nature Communications 7:10144 doi:10.1038/ncomms10144 (2016); Published 11 Jan 2016; Updated 16 Nov 2017

This Article contains an error in Fig. 4. Figure $4 \mathrm{~b}$ shows the structure of the rhodamine dye Alexa488, not the Alexa555 used in this work. The structure of Alexa555 is not known.

\footnotetext{
(c) (i) Open Access This article is licensed under a Creative Commons Attribution 4.0 International License, which permits use, sharing, adaptation, distribution and reproduction in any medium or format, as long as you give appropriate credit to the original author(s) and the source, provide a link to the Creative Commons license, and indicate if changes were made. The images or other third party material in this article are included in the article's Creative Commons license, unless indicated otherwise in a credit line to the material. If material is not included in the article's Creative Commons license and your intended use is not permitted by statutory regulation or exceeds the permitted use, you will need to obtain permission directly from the copyright holder. To view a copy of this license, visit http://creativecommons.org/licenses/by/4.0/
}

(C) The Author(s) 2017 